\title{
Forum
}

\section{Crabs and kairos: a reply to Lele and Igoe}

A lthough said to be an aphorism, I have seen it myself: blue crabs are unable to escape from a basket because each time one gets a claw over the edge and is ready to climb out, another crab grabs it and pulls it down. I worry that social scientists, with the causes they find important, and conservationists, with the causes they find important, are holding each other down. Jointly we have more important issues that we could approach together to convince the world that our causes together merit more significant attention and support than they are currently receiving. Figures on U.S. spending in 2008 illustrate the problem confronting us: in 2008 the USA spent USD 2.6 billion on its national parks, USD 34 billion on non-military foreign aid, and a staggering USD 700 billion on defence (rounded figures; US Census Bureau, 2011). Working together should not be optional.

In a few key places the response to my essay from Lele (2011) is precise rather than accurate. Neither social science nor conservation is a discipline practised by only academics, applied scientists, government employees, the staff of NGOs, or activists. Both are practised by all of these categories of people in addition to many others. Neither of these disciplines can be considered to be largely supported by public funds but rely on a wide variety of support. I suggest that very few conservationists would consider, as Lele claims, that conservation is the sole guide to action. I think he is equally wrong to say that a conviction in the importance of conserving the non-human world means we are blind to the needs of humans. It is just these sorts of broad-gauge rhetorical claims that are keeping us from cooperating, doomed forever to be relegated to the margins of society.

In his response Igoe (2011) argues that there is no clear line between the communities of conservationists and of social scientists, a fact with which I agree and failed to make strongly enough. This is a reason for hope for all who inhabit one community or the other-or both-and it should make us even more careful about assigning responsibility, blame, or even credit to one group or another.

Igoe finishes with the question: 'given all this nuanced analysis, what is preventing more effective communication and engagement?' This is the right question. Together we rise, or together we will remain in our basket. Moving from one sea creature metaphor to another, take a clutch of hatching baby turtles. Buried under several feet of sand they stand no chance of escaping individually; instead, through some instinctual coordination they all start to 'swim' to the surface, the coordinated action of each carrying all of them to freedom.

Kairos means a propitious moment for decision or action. We social scientists and we conservationists have reached such a moment. The prioritization exemplified by the spending of the U.S. and other governments cannot remain unchallenged: it is economically, politically, morally and ecologically wrong. By honest re-strengthening of what we can achieve together, and by learning from each other, we can turn our backs on a history of recrimination and blame, and forge a positive vision of a world rich in both cultural and biological diversity. We can do this together.

\section{References}

IGOE, J. (2011) Rereading conservation critique: a response to Redford. Oryx, 45, 333-334.

LELE, S. (2011) Rereading the interdisciplinary mindscape: a response to Redford. Oryx, 45, 331-332.

US Census Bureau (2011) The 2011 Statistical Abstract. U.S. Census Bureau, Washington, DC, USA [accessed 30 May 2011]. 